\title{
UNEMPLOYMENT AND GENDER EQUALITY WITHIN THE FAMILY IN PORTUGAL $^{1}$
}

\author{
Raquel Ribeiro², Lina Coelho and Alexandra Ferreira-Valente
}

Center for Social Studies, University of Coimbra, Portugal

\begin{abstract}
This paper analyses the impact of unemployment on the gender division of household work. A sample of 643 dual full-time employed couples and 160 with an unemployed partner was considered. Variance analysis and chi-square tests were performed to analyse the differential impact of the spouses' employment status on the time devoted to domestic and parental work and on the division of household chores among partners. Results show that male unemployment increases men's participation in domestic work only on weekdays while female unemployment constrains women into domestic activities both on week and weekend days. Gender patterns of task division also showed to relate significantly to partners' employment status.
\end{abstract}

Keywords: domestic work, household chores, unemployment, gender inequality.

\section{Resumo}

Desemprego e Igualdade de Género na Família em Portugal

$\mathrm{O}$ artigo analisa o impacto do desemprego na divisão sexual do trabalho familiar. Foi utilizada uma amostra de 643 casais com duplo emprego a tempo completo e $160 \mathrm{com}$ um parceiro desempregado. Recorreu-se a análises de variância e testes de qui-quadrado para analisar o impacto diferencial da situação dos cônjuges face ao emprego sobre o tempo dedicado ao trabalho doméstico e parental e a divisão das tarefas familiares. Os resultados mostram que o desemprego dos homens aumenta a sua participação somente nos dias de semana, enquanto o desemprego feminino restringe as mulheres às atividades domésticas, todo o tempo. Os padrões de género na repartição de tarefas também revelaram depender de forma significativa da situação profissional dos cônjuges. de género.

Palavras-chave: trabalho doméstico, tarefas domésticas, desemprego, desigualdade

\section{Résumé}

\section{Chômage et Égalité de Genre au sein de la Famille aux Portugal}

Cet article analyse l'impact du chômage sur la division sexuelle du travail familial. Un échantillon de 643 couples employés à plein temps et 160 avec un partenaire chômeur a été considéré. Analyses de la variance et tests du chi carré ont été appliqués pour déterminer l'impact différentiel de la situation professionnelle sur le temps de travail domes-

1 This article was written within the scope of the project «FINFAM - Finances, Gender and Power: how are Portuguese families managing their finances in the context of the crisis?" (PTDC/IVC-SOC/4823/2012 - FCOMP-01-0124-FEDER-029372), financed by ERDF funds through the Operational Programme Factors of Competitiveness (COMPETE) and by national funds through the Foundation for Science and Technology (FCT).

2 Corresponding author: rmp.ribeiro@gmail.com 
tique et parental et sur la division des tâches ménagères. Les résultats montrent que le chômage des hommes fait accroître leur participation au travail domestique seulement en semaine tandis que le chômage des femmes les contraint aux activités domestiques tout le temps. Les profils de genre des tâches se relient aussi, de manière significative, à la situation professionnelle des partenaires.

Mots-clés: travail domestique, tâches ménagères, chômage, inégalité des sexes.

\section{Consequences of the crisis for gender equality}

As men were the major actors in financial markets and in political decision making and the sectors mostly affected by the crisis were male dominated (manufacturing, construction and finance), the Great Recession has been termed a «he-cession» (Annesley and Scheele, 2011; Maier, 2011), suggesting the end of men's dominance in the economic and political world.

In fact, in the beginning of the crisis, unemployment in construction and manufacturing mostly affected men (Bettio et al., 2012; Leschke and Jepsen, 2012; Maier, 2011; Mills et al., 2014). In Europe, male employment dropped to 1997 levels while female employment registered only a slight decrease. Sex segregation of jobs therefore led to the convergence of male and female unemployment rates (10.8\% and $10.9 \%$, respectively, at the end of 2012). Yet, the decrease in gender gaps was not due to an improvement in women's situation but to a faster deterioration of men's situation (European Commission, 2013; Ferreira, 2013).

Although female employment was protected in the first phase of the crisis, female dominated sectors (public administration, health and education) have been mostly affected by subsequent fiscal consolidation measures, thus reducing the prospects of a recovery for female employment (Bettio et al., 2012; Leschke and Jepsen, 2012; Maier, 2011). The International Labour Organization [ILO] predicts female unemployment rates in the developed economies will only gradually decline to $8.2 \%$ in 2018 , whereas male rates are expected to reduce to $7.6 \%$ (ILO, 2014). Since the public sector has been crucial for women's economic integration (by providing well-paid quality jobs and social services and transfers), austerity measures represent a major challenge for gender equality. They not only undermine equality in paid work and economic independence but may cause an ideological backlash (Karamessini and Rubery, 2013). In fact, results of the European Social Survey show that as jobs became scarce in Denmark and the United Kingdom, more people came to believe men had more right to jobs than women (Leschke and Jepsen, 2012).

As such, the crisis threatens to undermine years of progress towards Millennium Development Goals and to jeopardize the targets of Europe 2020 Strategy in what relates to gender equality and employment (European Commission, 2013; European Women's Lobby [EWL], 2012; United Nations [UN], 2013).

Notwithstanding, the current crisis may impact the situation of women quite diversely from past recessions. Women currently account for a much 
greater proportion of employment, pay gaps generally become smaller and households living on two incomes have increased significantly. Consequently, a man's job loss tends to create a female breadwinner, while a woman's job loss soundly impacts household income (European Institute for Gender Equality [EIGE], 2013a; Maier, 2011; Smith, 2009).

Since paid work is gendered and impacts on unpaid work (Antonopoulos, 2009; Coltrane, 2000; Otobe, 2011), we may expect that, besides its economic consequences, the crisis will also have major effects on the relations between men and women within the family. Those effects are likely to depend on the pre-existing level of gender equality.

Several studies have addressed the gendered consequences of the crisis on the labour market (Annesley and Scheele, 2011; Maier, 2011; Otobe, 2011; Smith, 2009). Contrariwise, little is known on how unemployment is affecting household work division (Antonopoulos, 2009).

Extending prior research (Ribeiro, Coelho and Ferreira-Valente, 2015), this study aims to analyse the differential impact of female and male unemployment on the division of housework by couples, thus contributing to the gendered interdisciplinary analysis of the crisis (e.g. Annesley and Scheele, 2011; Antonopoulos, 2009; European Commission, 2014; Karamessini and Rubery, 2013; Maier, 2011; Otobe, 2011; Smith, 2009). To achieve this goal it builds on data from a national survey on the crisis' effects on Portuguese families with children (Coelho et al., 2014; Ferreira-Valente and Coelho, 2015).

\section{Situation of women and men in Portugal}

The Portuguese economy only emerged from recession in 2014, with an unemployment rate of $14.1 \%$, which compares to $9.2 \%$ in 2007 . Male and female unemployment reached $13.7 \%$ and $14.5 \%$, respectively, figures that rose from $8.7 \%$ and $9.7 \%$ in 2007 (Eurostat, 2015).

The crisis impacted on both men's and women's employment but in different moments, sectors and occupational categories. The year 2009 was the worst for men, while 2011 was the worst for women. Between 2008 and 2011 men lost ten times more jobs than women, especially as salaried employees in manufacturing and construction. Women lost more jobs as self-employed, unpaid family workers and employers (twice as much as men), in agriculture, manufacturing and private households (Ferreira, 2013).

As a result, male and female employment rates dropped: from $73.6 \%$ and $61.8 \%$ in 2007, respectively, to 63.5\% and 57.9\% in 2013 (Eurostat, 2015). Still, Portugal continues to show above average figures on female full-time equivalent employment in the European Union (EIGE, 2013a), with one of the highest percentages of mothers of small children working full time (Ferreira, 2013; Mills et al., 2014).

From a very low rate of $13.1 \%$ of women's participation in the labor market 
in the 1960s (Wall, Aboim, and Cunha, 2010), Portugal then moved into a process of rapid economic and social transformation within which the mass entry of women into the labour market was crucial (Coelho and Ferreira-Valente, 2014; Ferreira, 2013; Ribeiro, 2005; Wall, Aboim, and Cunha, 2010). This change was strengthened by a major policy shift after the democratic revolution of 1974, when equality between men and women was incorporated as a fundamental principle in the Portuguese Constitution (Amâncio, 2007; Rêgo, 2012). The feminization of the labour force reached $40 \%$ in 1991, and increased to $47 \%$ in 2008 (Eurostat, 1994, 2009, cit. in Ferreira, 2013).

However, the high female activity rate hides an uneven distribution of men and women, to the disadvantage of women, in occupational activities, hierarchical levels, status in employment, working times and wages (Coelho, 2010; EIGE, 2013a; Ferreira, 2013; Múrias and Ribeiro, 2012).

Portuguese society accompanied the evolution verified in other western countries concerning the decline of birth and marriage rates and the increase in the rates of divorce, cohabitation and births outside marriage (Amâncio, 2007; Ribeiro, 2005). A slight movement of men into domestic and parental work also took place, along with wide adherence to gender equality ideals (Perista, 2002; Wall, Aboim, and Cunha, 2010). Yet, differentiated gender roles within the family and asymmetric housework division still prevail in most families (Amâncio, 2007; EIGE, 2013a; Perista, 2010; Poeschl, 2000; Múrias and Ribeiro, 2012). Women's role still relates to household and care work, in spite of their massive participation in employment. Therefore, women mostly endure a «double workload», as time devoted to family work adds to paid work time (Afonso and Poeschl, 2006; Amâncio, 2007; Wall, Aboim, and Cunha, 2010).

The ongoing austerity policies, adopted to reduce public budgetary deficits, tend to produce detrimental effects to advancements in gender equality. Cuts in public provision lead to a reprivatisation of care and to a shift towards a more familialist welfare system (EWL, 2012), thus reinforcing the traditional informal welfare society, whose main pillar is the unpaid work of women (Ferreira, 2013). Besides, the suppression of public jobs, especially in the social sectors, mostly affects women and may lead to a return to traditional gender roles (Leschke and Jepsen, 2012; Karamessini and Rubery, 2013).

Furthermore, wage cuts in public sectors tend to induce reduced demand for domestic help, thus also decreasing job opportunities for uneducated women (Coelho, 2010; Ferreira, 2013). In fact, between 2008 and 2014 female jobs in "private households with employed persons» dropped by 34\%, from 173.4 to 114.4 thousand (Statistics Portugal, 2015). As a result, middle-class women are compelled to do more of their own domestic work and, as «there is an uneven distribution of power and resources between women and men in the household, it is probably correct to surmise that this means an added workload for women» (Ferreira, 2013: 224). The expansion of women's unpaid domestic work may also imply a relative disinvestment in professional careers, threatening their occupational status. 
The crisis may thus have a disproportionately negative impact on women (EWL, 2012), both by decreasing female employment and by widening gender pay gaps, as has been the case in Portugal in recent years ${ }^{3}$. In spite of their higher average levels of education, Portuguese young women seem to be in a particularly vulnerable situation, which creates gloomy perspectives for the future 4 .

\section{Present study}

Extant literature has showed that economic dependence relates to power relations within couples, by putting at a disadvantaged bargaining position the partner with smaller resources (e.g. Coelho, 2014, Coelho et al. 2014; Vogler and Pahl, 1994). In so far as unemployment creates or aggravates existing asymmetries of monetary and material resources within couples, it is likely to also aggravate gender inequalities.

In spite of advancements in gender equality, the division of household labour continues to be imbalanced in all countries, to the disadvantage of women, despite differences in magnitude (Bianchi, Sayer, Milkie, and Robinson, 2012; EIGE, 2013a). Several authors have attempted to explain this imbalance (Bianchi, Milkie, Sayer and Robinson, 2000; Coltrane, 2000; Mikula, 1998; Poeschl, 2000; Shelton and John, 1996). According to the time availability hypothesis, men usually spend more time in outside employment than women, thus having less time available for housework. This would justify women's greater participation in domestic tasks. In a different but complementary perspective, the relative resources hypothesis postulates that the partner with more resources uses the bargaining power conveyed by resources to perform less housework. As men usually have more resources (e.g. higher earnings, education and occupational prestige), they would do less household work than women. Finally, the gender role ideology hypothesis justifies imbalances in housework by adherence to traditional gender roles, according to which men are the main breadwinners, while women are the housekeepers and primary caregivers.

Time being «the ultimate scarce resource» (Bryson, 2007: 59), we may expect unemployment to prompt a reorganization of the couple's use of time in order to increase time devoted to household tasks by the unemployed partner. Unemployment might therefore be a key factor in determining the gendered division of work within the family.

This study aims to assess the differential impact of female and male unemployment on unpaid work within Portuguese couples. For that purpose we analy-

3 Eurostat (2015) figures show the overall unadjusted gender pay gap went up from $8.5 \%$ in 2007 to $13 \%$ in 2013.

$4 \quad$ For under 25 year old persons, unemployment rates were $35.4 \%$ for women and $32.3 \%$ for men by the end of 2014 (Eurostat, 2015). 
sed how the gender division of both time and household chores relate to three diverse occupational combinations by partners: both full-time employed, man full-time employed/woman unemployed, woman full-time employed/man unemployed.

Following previous studies showing there has been no major changes in family life organization in Portugal (Perista, 2002, 2010; Poeschl, 2000; Wall, Aboim, and Cunha, 2010), we anticipate the division of household work to still conform to traditional gender roles, with women devoting more time to it than their male partners.

Moreover, in accordance with both the time availability and the relative resources hypotheses, and following results of previous studies (Afonso and Poeschl, 2006; Ribeiro, Coelho and Ferreira-Valente, 2015), we also expect unemployment to be associated both with further involvement in domestic and parental work and less participation in financial chores. Notwithstanding, this may be disproportionally so in case of female unemployment since, in such a case, unemployment disadvantages cumulate with those coming out of traditional gender roles.

\section{Method}

The study builds on data gathered by a quantitative survey on the effects of the crisis on Portuguese heterosexual couples with children (Coelho et al., 2014; Ribeiro, Coelho and Ferreira-Valente, 2015). The questionnaire was applied to a quasi-representative sample of the population in terms of residence area and education levels ${ }^{5}$.

To fulfil the study's purposes we selected from the sample the couples in which: a) both partners were full-time employed; b) one of the partners was unemployed while the other was full-time employed. We therefore excluded couples with two unemployed partners or any other occupational situation (part time employed, retired, housekeeper).

\section{Participants}

From the total sample of 1001 households, $803(80.2 \%)$ fulfilled the inclusion criteria. From those, $643(80.1 \%)$ were dual full-time employed couples, $74(9.2 \%)$ included male unemployment and $86(10.7 \%)$ had female unemployment. Most respondents were women $(58.2 \%)$. Nevertheless, respondents of both sexes were equally distributed among the three groups considered $\left(\chi^{2}(2)=2.20, p=.333\right)$.

For a full description of the sampling procedure and sample characteristics see Alexandra Ferreira-Valente and Lina Coelho (2015). 
The partners' age ranged from 17 to 60 years old (Men: $M=42.01, S D=6.41$; Women: $M=40.27, S D=6.09$ ). Most couples were married $(80.8 \%), 9.3 \%$ cohabited with legal recognition and $9.3 \%$ with no legal recognition. Time of cohabitation varied between 1 and 34 years $(M=13.93, S D=7.57)$. Most couples cohabited with one $(50.1 \%)$ or two children $(43.1 \%)$. A minority (9.1\%) belonged to nonnuclear families.

\section{Instrument and procedure}

The full survey questionnaire comprised 54 closed or semi-closed questions (for a complete description of the instrument see Coelho et al., 2014; and FerreiraValente and Coelho, 2015). In order to achieve a broad range of participants across the country, data was collected by both an online survey tool (LimeSurvey) and traditional paper-and-pencil techniques, from March to August 2014.

For the purposes of the study we considered questions on the couple's occupational situation and on the gender division of family work referring to:

a) Average daily time devoted to domestic work (cleaning the house, washing the car, cooking, doing minor repairs, etc.) on weekdays and on weekends, separately;

b) Average daily time devoted to child care (playing, giving bath, helping with homework, talking, etc.) on weekdays and on weekends, separately;

c) Patterns of time allocation (mostly the woman; equal; mostly the man; mostly another family member; mostly other persons) to several household chores (laundry, housecleaning, cooking, minor repairs, taking children to school, caring for the sick, washing the car, shopping, paying the bills, dealing with taxes, managing accounts, dealing with loans and/or savings).

\section{Data analysis}

To assess gender differences regarding average time devoted to domestic and parental work we computed four variables on the differential of hours devoted by partners (woman's less man's hours) to: domestic work on weekdays, domestic work on weekends, child care on weekdays and child care on weekends. Answers mentioning more than 18 hours per day were not considered.

In order to analyse the differential impact of the couple's employment status on the time devoted to domestic and parental work, several variance analysis (one way ANOVA) on the abovementioned variables were performed. In the case of violation of the assumption of homogeneity of variances, we planned to use the Welch correction and the Games-Howell test to assess differences between groups (Marôco, 2014). 
Chi-square tests were performed to examine whether partners' participation in household chores depended on their employment status. For this purpose household tasks performed mostly by a third person were treated as «equal sharing». We planned to run the Monte Carlo simulation (Marôco, 2014) in the cases where less than $80 \%$ of cells had expected counts lower than 5 .

\section{Results}

\section{Time devoted to domestic and child care work}

Figure 1 shows the average number of hours devoted by men and women to domestic work and child care and the average gender gap, separately for week and weekend days.

Figure 1: Domestic and child care hours of work (left scale) and gender gap (right scale)
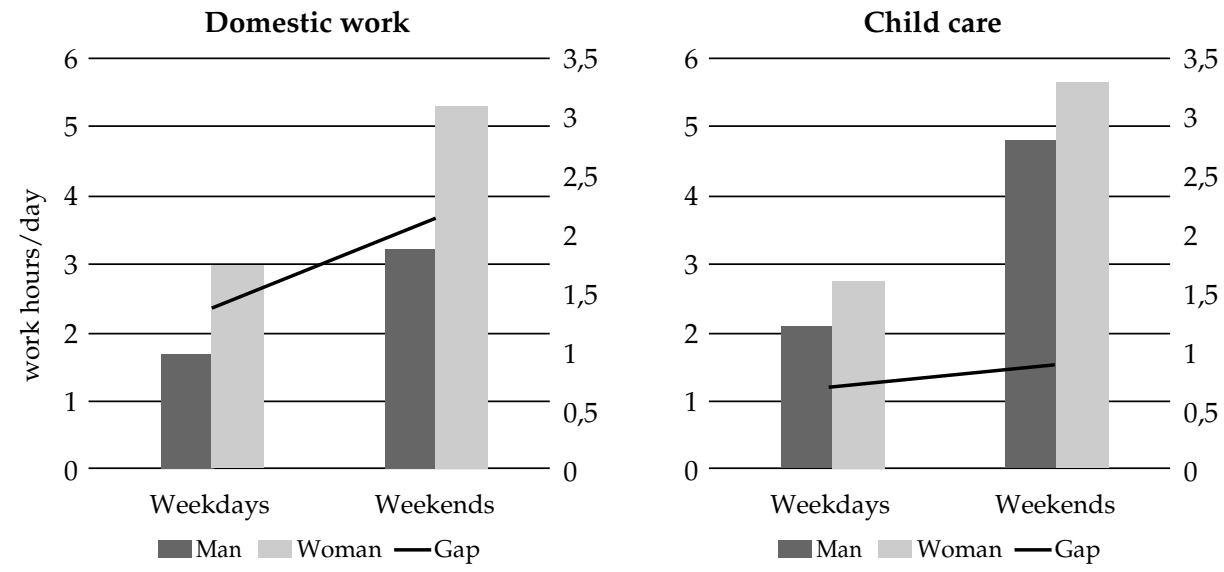

As expected, results show Portuguese women still spend more time in domestic and child care work than their male partners. This is in accordance with the findings of several studies showing that patterns of time allocation to unpaid work (domestic and care work) are marked by a profound asymmetry penalizing women (Bianchi, Sayer, Milkie and Robinson, 2012; EIGE, 2013a, 2013b; European Commission, 2014; Perista, 2002, 2010).

Results of the variance analysis on the differential impact of the employment status on the time devoted to domestic work and child care are displayed in Table 1.

Results show that time spent in domestic and parenting work depends on the couple's employment status. As regards weekdays, women devote more than an additional half hour to child care $(M=0.60, S D=1.55)$ and more than an addi- 
Table 1

Average gender gaps in domestic work and child care (hours)

\begin{tabular}{lcccc}
\hline & Both employed & Man employed & Woman employed & $\mathrm{F}$ \\
\hline Domestic work (weekdays) & $1.31 \mathrm{a}$ & $-.64 \mathrm{~b}$ & $3.67 \mathrm{c}$ & $42.37^{* * *}$ \\
Domestic work (weekend) & $2.01 \mathrm{a}$ & $2.01 \mathrm{ab}$ & $3.23 \mathrm{~b}$ & $4.96^{* *}$ \\
Child care (weekdays) & $.60 \mathrm{a}$ & $-.63 \mathrm{~b}$ & $2.42 \mathrm{c}$ & $23.50^{* * *}$ \\
Child care (weekend) & .84 & .53 & 1.44 & 1.66 \\
\hline
\end{tabular}

Source: Ragioneria Generale dello Stato, Conto annuale. http://www.contoannuale.tesoro.it/

tional hour to domestic chores $(M=1.31, S D=1.70)$ than men when both are fulltime employed. In the case of unemployed women, the corresponding time gaps increase to more than 2 hours for child care $(M=2.42, S D=2.91)$, and more than 3 and a half hours for domestic work $(M=3.67, S D=2.51)$. Contrariwise, in the case of male unemployment, the gender gap reverses on weekdays, as male time work becomes higher than female time by a little more than a half hour, both for child care $(M=-0.63, S D=2.60)$ and domestic work $(M=-0.64, S D=3.84)$. These results thus suggest that male unemployment favours higher involvement of men in both domestic and parental work.

However, results also show that women devote more time than men to unpaid work on weekends even when they are full-time employed. The time gap for domestic work exceeds two hours when either both spouses or the woman work full time $(M=2.01, S D=3.06 ; M=2.01, S D=4.06)$, and more than three hours when the woman is unemployed $(M=3.23, S D=3.67)$. In what concerns child care, the time gap on weekends is not statistically significant, a result which is consistent with studies showing the emergence of new models of masculinity in Portuguese society, including active paternity (Wall, Aboim, and Cunha, 2010).

\section{Gendered patterns of unpaid work}

Results of the chi-square tests (see Table 2) show that partners' participation in such tasks as doing the laundry, making small repairs and washing the car is independent from their employment status. However, these chores are clearly gendered: doing the laundry is almost exclusively done by women, while small repairs and washing the car are mostly performed by men.

In contrast, all the other tasks (housecleaning, cooking, grocery shopping, paying the bills, managing accounts and dealing with loans and/or savings) relate significantly to the partners' employment status.

In dual full-time employed couples, cooking and housecleaning were performed by women in more than $65 \%$ of the cases. Grocery shopping, taking care of the sick and taking children to school were either predominantly performed 
by women or equally divided. Men assumed these tasks more often in only a small percentage of the couples. In what relates to these tasks, results do suggest that male unemployment tends to reduce women's burden, the exception being care of sick relatives. This is consistent with findings by Karin Wall, Sofia Aboim and Vanessa Cunha (2010), who identified unemployment as an event inducing greater male participation in household and parenting work. Still, our data also shows that unemployed men regularly did cooking, house cleaning and grocery shopping in less than a quarter of the households, and in just over $37 \%$ they took children to school. Notwithstanding, their full-time employed female partners continued to carry out most tasks: in $77 \%$ of the cases they did the laundry, and in over $40 \%$ all other housework. Contrariwise, female unemployment appears to significantly increase female work in the abovementioned domestic tasks, while male prevalence becomes drastically reduced, to negligible figures.

Table 2

Gender patterns in household chores (percentages and chi-square values)

\begin{tabular}{|c|c|c|c|c|c|c|c|c|c|c|}
\hline & \multicolumn{3}{|c|}{ Both employed (\%) } & \multicolumn{3}{|c|}{ Male employed (\%) } & \multicolumn{3}{|c|}{ Female employed (\%) } & \multirow[b]{2}{*}{$\chi^{2}$} \\
\hline & 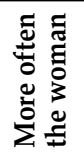 & 葾苛 & 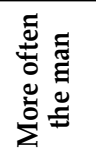 & 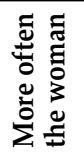 & 㤀苛 & 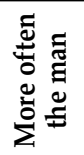 & 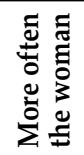 & 氶苛 & 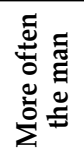 & \\
\hline Doing the laundry & 80.4 & 13.6 & 5.9 & 77.0 & 9.5 & 13.5 & 87.2 & 8.1 & 4.7 & 9.37 \\
\hline Making small repairs & 6.6 & 11.8 & 81.6 & 11.1 & 15.3 & 73.6 & 8.2 & 16.5 & 75.3 & 4.52 \\
\hline Washing the car & 10.4 & 21.4 & 68.2 & 12.1 & 15.5 & 72.4 & 13.0 & 18.2 & 68.8 & 1.76 \\
\hline Cooking & 66.9 & 21.2 & 11.9 & 52.7 & 23.0 & 24.3 & 73.8 & 20.2 & 6.0 & $14.42^{* *}$ \\
\hline Housecleaning & 65.5 & 30.3 & 4.2 & 48.6 & 35.1 & 16.2 & 82.5 & 15.3 & 1.2 & $35.92^{* * *}$ \\
\hline Grocery shopping & 41.7 & 44.7 & 13.6 & 43.2 & 33.8 & 23.0 & 47.6 & 46.4 & 6.0 & $10.91^{*}$ \\
\hline Caring for the sick & 52.2 & 43.0 & 4.9 & 55.0 & 40.0 & 5.0 & 78.9 & 19.3 & 1.8 & $14.41^{* *}$ \\
\hline Taking children to school & 138.6 & 43.2 & 18.3 & 33.9 & 28.8 & 37.3 & 64.6 & 24.6 & 10.8 & $30.15^{* * *}$ \\
\hline Dealing with taxes & 26.0 & 28.0 & 46.0 & 47.2 & 22.2 & 30.6 & 28.4 & 28.4 & 43.2 & $14.70^{* *}$ \\
\hline Paying the bills & 28.6 & 29.5 & 41.9 & 52.8 & 23.6 & 23.6 & 37.5 & 22.5 & 40.0 & $20.09^{* * *}$ \\
\hline Managing accounts & 19.7 & 54.5 & 25.8 & 50.7 & 35.2 & 14.1 & 25.6 & 41.5 & 32.9 & $38.47^{* * *}$ \\
\hline $\begin{array}{l}\text { Dealing with loans and/ } \\
\text { or savings }\end{array}$ & 20.5 & 40.0 & 39.5 & 54.3 & 24.3 & 21.4 & 19.7 & 38.2 & 42.1 & $40.55^{* * *}$ \\
\hline
\end{tabular}

Note: ${ }^{*} p<.05 ; * * p<.01 ; * * *<.001$

As regards financial tasks, results show that in dual full-time employed couples dealing with taxes and paying utilities bills were performed mostly by men, while managing bank accounts and dealing with loans and savings tended to be equally divided. Unemployment seems to produce noteworthy changes in this sphere only in the case of male unemployment, since the pattern of partners' participation in case of female unemployment is similar to that of dual employed couples. Still, for that matter, male unemployment induces increased participa- 
tion of women, seemingly suggesting that male unemployment, by creating female breadwinners, may contribute to enhancing gender equality within the family.

\section{Discussion}

Overall, our findings on time patterns of domestic work within couples are consistent with those of previous studies, showing there have been no major changes in family life organization, in spite of the massive entrance of women into the labour market and the wide dissemination of ideals of equality between men and women (EIGE, 2013b; European Commission, 2014; Perista, 2002, 2010; Poeschl, 2000). We may in fact infer there have been no major developments in the last 15 years in this matter, since the time we found to be devoted by men and women to family work does not substantially differ from results obtained in 1999 by the only survey on time uses ever held in Portugal to date (Perista, 2002). Even when having a full-time job women still bear most of the burden of domestic and care work.

Those findings also corroborate figures of the Gender Equality Index (GEI) as regards Portugal. In fact, although Portugal ranks above the European average in what concerns female full-time equivalent employment (a value of $46.3 \mathrm{com}$ pared to 41.0 for the EU-27 average), in the so-called «time domain» of the GEI the position is reversed, becoming 22.4 for Portugal and 38.8 for the EU average, respectively ${ }^{6}$ (EIGE, 2013a).

The intensity of the global workload borne by Portuguese women, especially the full-time employed mothers of young children, may thus constitute one of the main explanations for the differences found between men's and women's physical and mental self-assessed perception of their own health. In fact, results by Ferreira-Valente and Coelho (2015) show a negative association between mental and physical health and time devoted to housework. As referred by Mattingly and Bianchi (2003), not only does the second shift hamper women's possibility to enjoy free time to reinvigorate themselves, but their (scarce) free time is often contaminated by outside non-leisure activities or the presence of children. Women, therefore, feel more time pressure than men, and this may also negatively affect the assessment they make of their well-being and health.

Our results also show that the various household activities are strongly gendered, thus perpetuating traditional gender roles (Coltrane, 2000; Mikula, 1998; Perista, 2002; Poeschl, 2000). Women continue to perform mostly the more routine and time demanding tasks and those confined to the interior of the house (laundry, cooking, house cleaning, and caring for the sick) while men prevail in tasks related to repairing, cars and household finances.

6 Where 1 stands for absolute gender inequality and 100 for full gender equality. 
In what concerns the relation between unemployment and gender division of family work, results are partly in line with expectations and previous studies. Even though male participation in domestic chores is higher when the man is unemployed (Afonso and Poeschl, 2006; Wall, Aboim, and Cunha, 2010), his participation still does not exceed the female partner participation.

Results partly support the explanations given by both the time availability and the relative resources theories for the unbalanced division of household labor. For unemployed women, increased time availability and less monetary resources lead to higher participation in housework and child care. Diversely, for unemployed men that relation is only verified on weekdays while imbalance continues to prevail on weekends. These findings may be interpreted in line with the explanations proposed by Rosa-Marina Afonso and Gabrielle Poeschl (2006): during weekdays increased unemployed men's participation may be due to their need to remain active and maintain self-esteem. In fact, some recent studies show that «one response of fathers to job loss is a shift in anchoring identity from being a breadwinner to being an involved, active father» (Bianchi et al., 2012: 61). However, on weekends unemployed men continue to feel entitled to use free time for leisure activities. Contrariwise, unemployed women are not allowed to enjoy free time as they are expected to assume all the family tasks, all the time. On one hand, women may perceive household work as less arduous and themselves as less deserving of free time, on the other hand, they are responsible for providing the settings for family leisure activities, a role that may prevent them from enjoying any free-time (Mattingly and Bianchi, 2003). Results thus appear to confirm that gender ideology plays an important role in participation imbalance, as has been shown in studies on feelings of justice by partners in what regards housework division (cf. Mikula, 1998; Poeschl, 2000; Shelton and John, 1996).

Results regarding household financial chores are also partly in line with the proposal of Afonso and Poeschl (2006), since unemployment seems to reduce men's role in money issues. However, as male unemployment generally produces more severe drawbacks for family income than female unemployment, due to the prevailing gender pay gap (Coelho, 2010; EIGE, 2013a), that result may not mean an increase in women's financial autonomy but, on the contrary, an increased burden of responsibility. In fact, the income shortage may imply that financial tasks become, in such cases, much more time consuming, stressful and arduous tasks. Instead of an enhancement of gender equality, household financial chores may therefore mean a particularly painful extra burden for women, who become the ones in charge of «making ends meet» with an insufficient family income (e.g. Thorne, 2010).

The most surprising result relates to women's participation in financial chores, insofar as participation showed to be approximately similar for unemployed and full-time employed women. As a matter of fact, we would expect men to be predominantly in charge of such tasks, especially when they are the main breadwinners, in accordance with traditional gender roles. Still, this finding 
may mean that the increased participation of Portuguese women in the labour market has fuelled their own economic autonomy thus justifying greater decisional independence in financial matters. This confirms the results obtained by Ferreira-Valente and Coelho (2015) showing a greater prevalence of total or partial individuation in modes of couples' money management in Portugal than in other countries where this issue has been studied. Although this fact may suggest an actual progress in gender equality within the family, the overall findings regarding male participation in domestic work, regardless of the couple's employment status, allow us to conclude that progress in gender equity in domestic work have been limited. Male participation appears to continue to be seen as mere «help», while responsibility for household tasks continues to fall on women, in accordance with traditional gender roles (Afonso and Poeschl, 2006; Coltrane, 2000; Poeschl, 2000).

\section{Study Limitations}

Some limitations can be pointed to this study. First, information on the share of housework between spouses was provided by only one of them. Furthermore, the self-reported nature of the data allows for possible biases resulting from 'social desirability' in the answers given by respondents regarding household division of work. For this reason, results must be interpreted with caution. Moreover, the cross-correlational nature of the study does not allow establishing causal relationships between household labour participation and unemployment.

A comprehensive understanding of the differential impact of female and male unemployment on gender housework patterns would require control for socio-demographic characteristics of the partners. In fact, extant studies have shown that the socioeconomic status of couples may significantly determine the adherence to traditional gender roles (e.g. Poeschl, 2000) and that partners' homogamy in income, education and occupational status may also relate to housework division (e.g. Shelton and John, 1996) and to couples' money management arrangements (Ferreira-Valente and Coelho, 2015).

\section{Conclusions}

The study's results support extant literature alerting to the perverse effects the crisis might have on equality between women and men (Antonopoulos, 2009; Bettio et al., 2012; European Commission, 2014; EWL, 2012; Ferreira, 2013; Maier, 2011).

In a first moment, the current crisis appeared to be leading to a re-balancing of power between men and women, as reduction of jobs in male dominated sectors could induce the rise of female breadwinners. Yet, our results suggest that those changes may not be effective in what concerns intra-family gender relations. 
In Portugal, the working times of women continue to be longer than those of men due to the double workload associated with traditional gender roles. Additionally, female unemployment seems to lead to a reinforcement of the housekeeping role of women, while male unemployment only moderately contributes to alleviate the daily burden of working women on weekdays and give them no extra free time on weekends.

Since one of the greatest obstacles to gender equality are the barriers women face in the labour market (Rêgo, 2012), it is important to question the gendered effects of the increased 'deregulation' and policies that encourage women to leave the labour market. In fact, those measures had a negative impact on women in the past, illustrating how public policies addressed to tackle the consequences of the crisis on employment are not gender-neutral (Annesley and Scheele, 2011; EWL, 2012; Maier, 2011, Smith, 2009).

To prevent the crisis from undermining decades of advancements in labour market and gender equality (Antonopoulos, 2009; Bettio et al., 2012; European Commission, 2014; EWL, 20012; Maier, 2011) it is fundamental to evaluate the gender impacts of current austerity and structural reforming policies and reinforce the legitimacy of the quest for «more gender equality» (Maier, 2011; Smith, 2009).

\section{References}

Afonso, Rosa-Marina; Poeschl, Gabrielle (2006), «Representaciones del impacto de la situación de desempleo en las prácticas familiares», Revista de Psicología Social 21(3), 241-258.

Amâncio, Lígia (2007), "Género e divisão do trabalho doméstico - O caso Português em perspectiva», in Karin Wall, Lígia Amâncio (org.), Família e género em Portugal e na Europa, Lisboa, Imprensa de Ciências Sociais, 181-209.

Annesley, Claire; Scheele, Alexandra (2011), «Gender, capitalism and economic crisis: Impact and responses», Journal of Contemporary European Studies 19(3), 335-347.

Antonopoulos, Rania (2009), The current economic and financial crisis: A gender perspective, [online] available in http://www.levyinstitute.org/pubs/wp_562.pdf [seen on 10/03/2015].

Bettio, Francesca; Corsi, Marcella D'Ippoliti, Carlo Lyberaki, Antigone Lodovici, Manuela S. Verashchagina, Alina (2012), The impact of the economic crisis on the situation of women and men and on gender equality policies, [online] available in http:// ec.europa.eu/justice/gender-equality/files/documents/130410_crisis_report_en.pdf [seen on 10/03/2015].

Bianchi, Suzanne M.; Milkie, Melissa A.; Sayer, Liana C.; Robinson, John P. (2000), «Is anyone doing the housework? Trends in the gender division of household labor», Social Forces 79(1), 191-228.

Bianchi, Suzanne M.; Sayer, Liana C.; Milkie, Melissa A.; Robinson, John P. (2012), «Housework: Who did, does or will do it, and how much does it matter?», Social Forces 91(1), 55-63.

Bryson, Valerie (2007), Gender and the politics of time. Feminist theory and contemporary debates, Bristol, The Policy Press. 
Coelho, Lina (2010), Mulheres, familia e desigualdade em Portugal (PhD Thesis), University of Coimbra, Portugal, [online] available in https://estudogeral.sib.uc.pt/bitstream/10316/13833/1/DissertaçãoDout_Lina\%20Coelho.pdf [seen on 03/04/2014].

Coelho, Lina (2014), «My money, your money, our money: Contributions to the study of couples' financial management in Portugal», RCCS Annual Review 6(6), 83-101.

Coelho, Lina; Ferreira-Valente, Alexandra (2014), «The economic empowerment of Portuguese women at the crossroads: An accomplishment facing the tourniquet of the crisis», XVIII ISA World Congress of Sociology Conference Paper, 1-7.

Coelho, Lina et al. (2014), Finances, gender and power: How are Portuguese households managing their finances in the context of economic crises?-Preliminary Results, 91, CES, Coimbra, [online] available in http://www.ces.uc.pt/fct/Relatorio_1_FINFAM_Ver sao_1_Abril2014.pdf [seen on 01/04/2014].

Coltrane, Scott (2000), «Research on household labor: Modeling and measuring the social embeddedness of routine family work», Journal of Marriage and the Family 62, 1208$-1233$.

European Commission (2013), Report on progress on equality between women and men in 2012, [online] available in http://ec.europa.eu/justice/gender-equality/files/swd_ 2013_171_en.pdf [seen on 06/07/2014].

European Commission (2014), Report on progress on equality between women and men in 2013, [online] available in http://ec.europa.eu/justice/gender-equality/files/swd_ 2014_142_en.pdf [seen on 06/07/2014].

EIGE (2013a), Gender equality index - Country profiles, [online] available in http://eige. europa.eu/content/document/gender-equality-index-report [seen on 06/07/2014].

EIGE (2013b), Gender equality index report, [online] available in http://eige.europa.eu/content/document/gender-equality-index-report [seen on 06/07/2014].

EWL (2012), The price of austerity - The impact on women's rights and gender equality in Europe, Brussels, EWL.

EUROSTAT, [online] available in http://ec.europa.eu/eurostat [seen on 12/03/2015].

Ferreira, Virgínia (2013), «Employment and austerity: Changing welfare and gender regimes in Portugal», in Maria Karamessini; Jill Rubery (org.), Women and austerity The economic crisis and the future for gender equality, New York, Routledge, 207-227.

Ferreira-Valente, Alexandra; Coelho, Lina (2015), «Gestão das finanças conjugais em tempo de crise económica», in Isabel C. Silva; Marina Pignatelli; Susana M. Viegas (coord.), Livro de Atas do $1^{\circ}$ Congresso da Associação Internacional de Ciências Sociais e Humanas em Lingua Portuguesa 2015, AICSHLP, 4749-4765.

Ferreira-Valente, Alexandra; Coelho, Lina (2015), «La salute delle donne e la crisi economica nello studio pilota di in un paese del Mediterraneo europeo», in Ignazia Bartholini (ed.), Radicamenti discriminazioni e narrazioni di genere nel Mediterraneo, Milano, Guerrini Associati.

ILO (2014), Global employment trends 2014: Risk of a jobless recovery?, Geneva, International Labour Office.

Maier, Friederike (2011), «Will the crisis change gender relations in labour markets and society?», Journal of Contemporary European Studies 19(1), 83-95.

Mattingly, Marybeth; Bianchi, Suzanne M. (2003), «Gender differences in the quantity and quality of free time: The U.S. experience», Social Forces 81(3), 999-1030.

Marôco, João (2014), Análise estatística com o SPSS statistics, Pêro Pinheiro, Report Number.

Mikula, Gerold (1998), «Division of household labor and perceived justice: A growing field of research», Social Justice Research 11(3), 215-241. 
Mills, Melinda; Tsang, Flavia; Präg, Patrick; Ruggeri, Kai; Miani, Celine; Hoorens, Stijn (2014), Gender equality in the workforce: Reconciling work, private and family life in Europe, [online] available in http://www.rand.org/pubs/research_reports/RR462. html [seen on 10/03/2014].

Múrias, Cláudia; Ribeiro, Raquel (2012), «Ideias a desconstruir ou a reinventar: Questionando percursos tradicionais de liderança de mulheres e de homens», in Cláudia Múrias; Marijke de Koning (coords.), Lideranças partilhadas: Percursos de literacia para a igualdade de género e qualidade de vida, Lisboa, Fundação Cuidar O Futuro e Livpsic, 201-222.

Otobe, Naoko (2011), «Global economic crisis, gender and employment: The impact and policy response», International Labor Organization Working Paper 74, Geneva, ILO.

Perista, Heloísa (2002), «Género e trabalho não pago: Os tempos das mulheres e os tempos dos homens», Análise Social (37)163, 447-474.

Perista, Heloísa (2010), «Mulheres, homens e usos do tempo - quinze anos após a Plataforma de Acção de Pequim, onde estamos, em Portugal?», Revista de Estudos Demográficos 47, 47-63.

Poeschl, Gabrielle (2000), «Trabalho doméstico e poder familiar: Práticas, normas e ideais», Análise Social 35(156), 695-719.

Rêgo, Maria do Céu C. (2012), «Políticas de igualdade de género na União Europeia e em Portugal: Influências e incoerências», ex aequo 25, 29-44.

Ribeiro, Raquel (2005), As representações sociais da realização pessoal: Efeito do sexo e do estado civil. Master Dissertation. Porto, University of Porto.

Ribeiro, Raquel; Coelho, Lina; Ferreira-Valente, Alexandra (2015), «Economic crisis and unemployment: Consequences for gender equality within the family», in R. Cavallotti; C. León (ed.), Proceedings of the II International Conference Family and Society, Barcelona, IESF - UIC, 93-106.

Shelton, Beth A.; John, Daphne (1996), «The division of household labor», Annual Review of Sociology 22, 299-322.

Smith, Mark (2009), Analysis note: Gender equality and recession, Grenoble, Grenoble École de Management.

Statistics Portugal, [online] available in www.ine.pt [seen on 14/03/2015].

Thorne, Deborah (2010), «Extreme financial strain: Emergent chores, gender inequality and emotional distress», Journal of Family and Economic Issues 31, 185-197.

UN (2013), The millennium development goals report, New York, United Nations.

Vogler, Carolyn; Pahl, Jan (1994), «Money, power and inequality within marriage», Sociological Review 42(2), 263-288.

Wall, Karin; Aboim, Sofia; Cunha, Vanessa (Org.) (2010), A vida familiar no masculino. Negociando velhas e novas masculinidades, Lisboa, CITE.

\section{Acknowledgments}

The authors are grateful for contributions from research colleagues, namely Cristina C. Vieira for the construction of the instrument. We also thank all the people and institutions that contributed to the data collection process.

Raquel Ribeiro. Doutorada em Psicologia pela Faculdade de Psicologia e Ciências da Educação da Universidade do Porto. É atualmente docente no Mestrado em Temas de Psicologia na mesma Faculdade. rmp.ribeiro@gmail.com 
Lina Coelho. Doutorada em Economia pela Faculdade de Economia da Universidade de Coimbra (FEUC). É docente na FEUC e investigadora do Centro de Estudos Sociais da Universidade de Coimbra. lcoelho@fe.uc.pt

Alexandra Ferreira-Valente. Doutorada em Psicologia pela Faculdade de Psicologia e Ciências da Educação da Universidade do Porto. É atualmente docente na Universidade Lusíada e investigadora no ICVS - Instituto de Investigação em Ciências da Vida e Saúde da Universidade do Minho. mafvalente@gmail.com

Centro de Estudos Sociais, Colégio de S. Jerónimo, Largo D. Dinis, Apartado 3087 3000-995 Coimbra, Portugal

Artigo recebido em 23 de maio de 2015 e aceite para publicação em 29 de setembro de 2015. 